\title{
Strafgejebbuth
}

füir Das Deutfide Reid vom 15, Mat 1871

mit einem Inhang von widtigen Beftimmungen bes Gertiftsverfajiungsgefeges und ber Strafprozeporbmung.

\section{8um Gebraud}

für Polizeis, Sidherheits= unb Rriminalbeante

erläutert von

\section{Dr. $\mathfrak{A},(\mathfrak{G r o j \mathfrak { d }}$,}

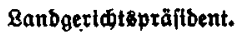

Sedifte Tuflage.

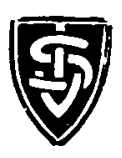

1923

Münđen, Berlin utnd Letpzìg.

9. Edweiger $\mathfrak{B e r l a g}$ (2) rtbur Gellier). 
